\title{
Factors affecting adventitious root formation in microcuttings of Malus
}

\author{
GJ De Klerk, J Ter Brugge \\ Centre for Plant Tissue Culture Research, PO Box 85, 2160 AB Lisse, The Netherlands
}

(COST Meeting, 21-23 May 1992, Dijon, France)

\begin{abstract}
Summary - Adventitious root formation (ARF) in conventional cuttings and microcuttings is a major problem in the vegetative propagation of many crops. We studied ARF in microcuttings of Malus. The rooting ability depended on the genetic background, the ontogenetic state (juvenile vs adult), the occurrence of dormancy, vitrification, the duration of the final propagation cycle and indolebutyric-acid (IBA) concentration during propagation. The timing of IBA application during the rooting treatment had a significant effect: postponement of the application resulted in a strong decrease in rooting. When rooting occurred under continuous light, instead of the standard dark condition, the IBA dose-response curve shifted to the right (to higher IBA concentrations). The timing of the main phases of ARF was established by 24-h pulses with benzyladenine (BAP) during the standard IBA treatment $\left(0.2 \mathrm{mg} / \mathrm{IBA} ; 20^{\circ} \mathrm{C}\right)$. The BAP-pulses strongly blocked rooting when given between $24-72 \mathrm{~h}$. We concluded from this that the differentiation into root-(pre)meristemoids occurred during that time. In correspondence with this, 24-h pulses with auxin had a maximum effect on rooting when applied during this period. We presume that the lag from $0-24 \mathrm{~h}$ represents a phase of dedifferentiation. The outgrowth phase of root-(pre)meristemoids occurred after $72 \mathrm{~h}$. After ca $9 \mathrm{~d}$ the roots emerged from the stem.
\end{abstract}

\section{adventitious root formation / Malus sp / regeneration}

Résumé - Facteurs influençant la formation de racines adventives sur les microboutures de Malus. La formation de racines adventives (FRA) sur les boutures ordinaires et sur les microboutures est un problème important pour la multiplication végétative de beaucoup de plantes cultivées. Nous avons étudié la FRA sur des microboutures de Malus. L'aptitude à l'enracinement varie avec le contexte génétique, le stade dans l'ontogenèse (juvénile ou adulte), l'état de dormance, la vitrification, la durée du cycle final de micropropagation et la concentration en acide indolebutyrique (IBA) pendant la propagation. Le moment où est appliqué l'IBA a un effet significatif : une application tardive se traduit par une forte diminution de l'enracinement. Quand l'enracinement a lieu en lumière continue, au lieu de l'obscurité habituelle, la courbe de réponse aux doses d'IBA est déplacée vers la droite (vers les concentrations d'IBA plus fortes). La chronologie des phases principales de la FRA a été établie au moyen de bouffées de benzyladénine $(B A P)$ de $24 \mathrm{~h}$, pendant le traitement standard à I'IBA $\left(0.2 \mathrm{mg} / \mathrm{IBA} ; 20^{\circ} \mathrm{C}\right)$. Les bouffées de BAP bloquent fortement l'enracinement quand elles sont données entre 24 et $72 \mathrm{~h}$. Nous en concluons que la différenciation de (pré)méristémoïdes de racines a lieu pendant cette période. De manière correspondante, des bouffées d'auxine de $24 \mathrm{~h}$ ont leur effet maximal sur l'enracinement pendant la même période. Nous supposons que la période d'inertie de 0 à 24 h représente une phase de dédifférenciation. La phase de croissance des (pré)méristémoïdes de racines a lieu après 72 h. Après environ 9 jours les racines émergent de la tige.

formation de racines adventives / Malus sp / régénération

\section{INTRODUCTION}

In perennial ornamental and woody plants, inbred lines are not available and a good cultivar can only be maintained by conventional vegetative propagation or by micropropagation. In the vegetative propagation of many crops, rooting of (micro)cuttings is the most crucial step (Van Telgen et al, 1992). Almost 60 yr ago, Thimann and Went (1934) reported that adventitious root formation (ARF) was promoted by addition of aux- in. Today, application of auxin is still the main tool to achieve rooting. Cuttings of many crops, however, do not readily undergo ARF after application of auxin. Rooting can be improved: 1) by adapting the condition of the (micro)cutting; and 2) by optimizing the rooting treatment. In this article, we examine how various conditions during the propagation and the rooting phases affect rooting in microcuttings of Malus. Since the various phases in the rooting process probably have different requirements, it is important to establish 
the timing of these phases. We will show how the successive phases of ARF can be distinguished by their different sensitivities towards cytokinin and auxin.

\section{MATERIALS AND METHODS}

Shoot production of Malus 'Jork', 'Nicolai', 'Elstar' or 'Golden Delicious' and Cydonia oblonga 'Leskovacz' was maintained in 6-wk subculture cycles at $20^{\circ} \mathrm{C}$. The standard conditions for propagation (De Klerk et al, 1990) were altered as indicated.

The rooting treatment conditions were as described previously (De Klerk et al, 1990). In short, shoots of $1-2 \mathrm{~cm}$ were havested $6 \mathrm{wk}$ after subculture and transferred to a medium with $0.2 \mathrm{mg} . \mathrm{l}^{-1}$ indolebutyric acid (IBA) and $1 \mathrm{mg} . \mathrm{I}^{-1}$ riboflavin. After $7 \mathrm{~d}$ in the dark, the shoots were transferred to the light $(16 \mathrm{~h}, 30$ $\left.\mu E \cdot m^{-2} \cdot s^{-1}\right)$. These standard conditions were altered as indicated. Shoot segments $(2.5 \mathrm{~mm}$ in length) were placed horizontally on rooting medium in Petri dishes. Rooting was scored after 3 wk as the percentage of rooted shoots and as the mean number of roots per rooted shoot. Thirty shoots were used for each determination.

To establish the period of maximal sensitivity towards cytokinin, shoots were cultured on the standard rooting medium with $0.2 \mathrm{mg} . \mathrm{I}^{-1} \mathrm{IBA}$. At the indicated times, they were transferred for $24 \mathrm{~h}$ to the same medium (also with $0.2 \mathrm{mg} . \mathrm{I}^{-1}$ IBA) to which $0.2 \mathrm{mg} .1^{-1}$ 6-benzylaminopurine (BAP) was added. To establish the period of maximal sensitivity towards auxin, shoots cultured on hormone-free rooting medium were transferred at the indicated times for $24 \mathrm{~h}$ to the same medium with $0.5 \mathrm{mg} . \mathrm{I}^{-1} \mathrm{IBA}$.

\section{RESULTS AND DISCUSSION}

\section{The condition of the transplanted shoot}

\section{Genetic background}

The various cultivars and species under examination showed large differences in rooting (data not shown). Such differences have been observed by many researchers (eg Haissig and Riemenschneider, 1988). The genetics of root regeneration has not yet been examined. In regeneration of shoots and somatic embryos, though, crossings have been made between recalcitrant and regenerating genotypes. Only a few genes may be responsible for the recalcitrance to regenerate (Reisch and Bingham, 1980). It is not known whether the same block occurs in all or many of the recalcitrant crops. The functions of the 'regeneration' genes are also not known. As yet, 2 proteins required for regeneration have been identified: viz a cationic peroxidase (Cordewener et al, 1991) and a chitinase (De Jong et al, 1992) in somatic embryogenesis of carrot. Since these proteins were not synthesized because of chemical treatment (with the glycosylation inhibitor tunicamycin) or mutagenesis, respectively, it is not known whether they are required for the normal functioning of a plant and whether they may be lacking in normal plants.

\section{Developmental state}

Cuttings from seedlings of most woody plants root readily. However, the capability of juvenile plants to root is lost partly or completely with the transition to the adult state. Depending upon the genotype, this transition occurs a few wk or many yr after germination. Its mechanism is unknown (Hackett, 1985). In tissue culture, an adult plant may rejuvenate and again become capable of ARF (Moncousin and Ducreux, 1984). Figure 1 shows that repeated subculture enhanced the responsiveness to auxin. Poor rooting of microcuttings of many woody crops and the fluctuations in rooting from one subculture to the other (Denissen et al, 1992) may be due to incomplete rejuvenation.

Dormancy in buds of plants grown under natural conditions is induced by short day-length or low temperature (Powell, 1987). Lack of rooting in cuttings from dormant plants has frequently been reported. Cold treatment restored the rooting ability in dormant Abies cuttings (Wise et al, 1985). In vitro, the development of dormancy has only been extensively studied in bulbs (Delvallée et al, 1990; De Klerk, 1992). Related to these studies, we also examined dormancy in Malus. Culture under short day-length conditions had no effect, but at low temperature $\left(12^{\circ} \mathrm{C}\right)$ proliferation in vitro was completely blocked. Rooting of shoots from the $12{ }^{\circ} \mathrm{C}$ cultures was significantly reduced (fig 2). It should be noted that dormancy is not an all-or-nothing phenomenon, but a matter of degree. Thus, a low level of dormancy may develop and slow down proliferation without blocking growth completely. Such a low level of dormancy occurs in Malus in vitro: cold treatment of Malus tufts enhances the propagation factor (De Klerk, 1992) and increases fresh weight (Elagoz and de Klerk, unpublished observations) by 

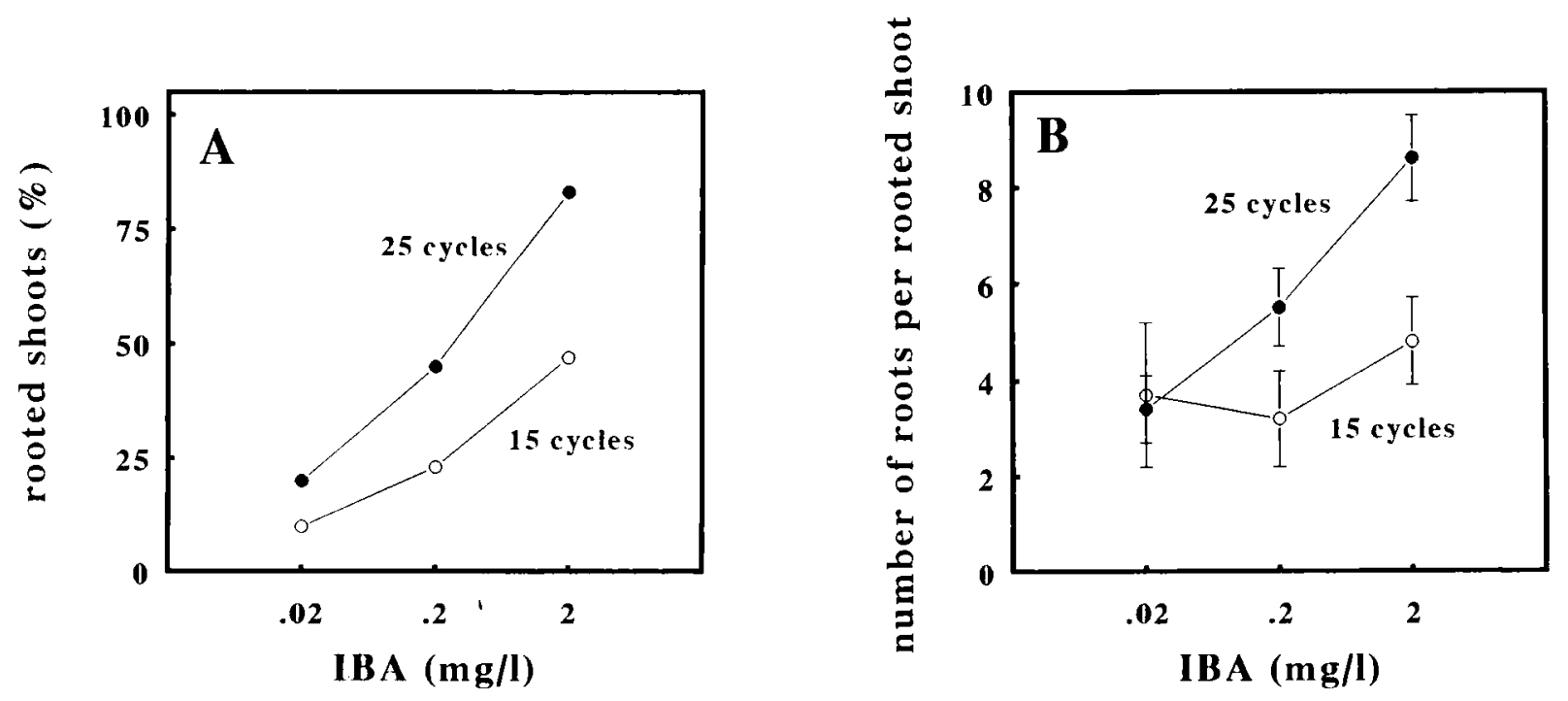

Fig 1. Rooting of Malus Nicolai with addition of increasing concentrations of IBA. The cultures had been subcultured 15 or 25 times. A: percentage of rooting; B: No of roots per rooted shoot.

$50-100 \%$ in the next subculture cycle. Currently, we examine whether this low dormancy has an effect on rooting capability.

\section{Positional and temporal factors}

As a rule, 'young' tissues (ie tissues that have recently been formed from meristematic tissues) have a higher capability for organogenesis than 'old' tissues. However, segments of stems that are close to the apical bud (and therefore younger than segments at the basal end) have a lower ability for root regeneration than the other segments (fig 3). Close to the base, the rooting ability is also lower. In conventional cuttings, this

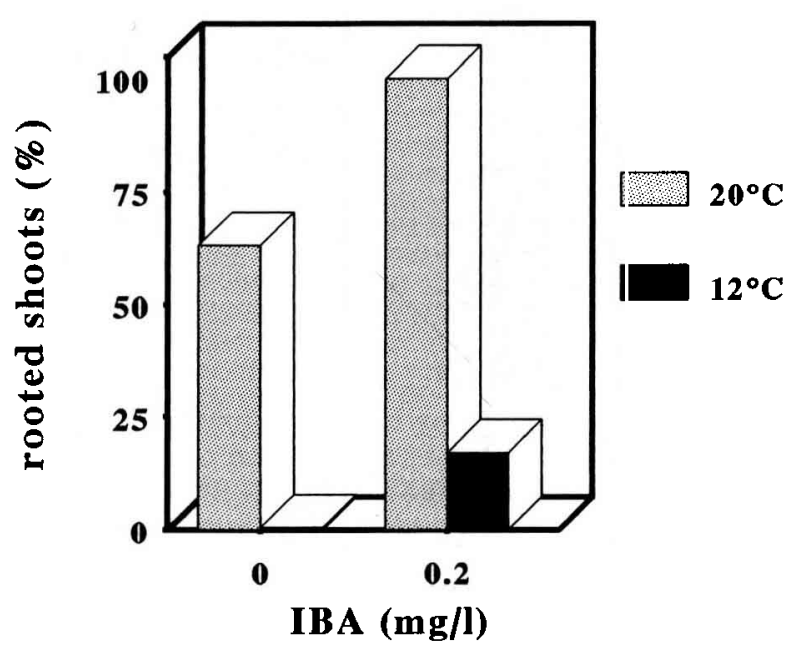

Fig 2. Rooting percentages of shoots of Malus Jork propagated at 20 or $12{ }^{\circ} \mathrm{C}$. rooting ability gradient has also been observed (Hansen, 1986) and is explained by a gradient in the stem from juvenile to adult, or by increased shading of the basal part of the stem by the leaves. Both explanations seem to be inappropriate in our system.

Early in a subculture cycle, the shoots had a low rooting ability. The best time for harvest was 5 or 6 wk after subculture (fig 4). We frequently observed that rooting again decreased in shoots harvested after 7 or 8 wk (fig 4; data for August). Figure 4 also shows the wide differences between the results obtained in 2 successive subculture cycles, even though all conditions were apparently the same. Wide differences in rooting

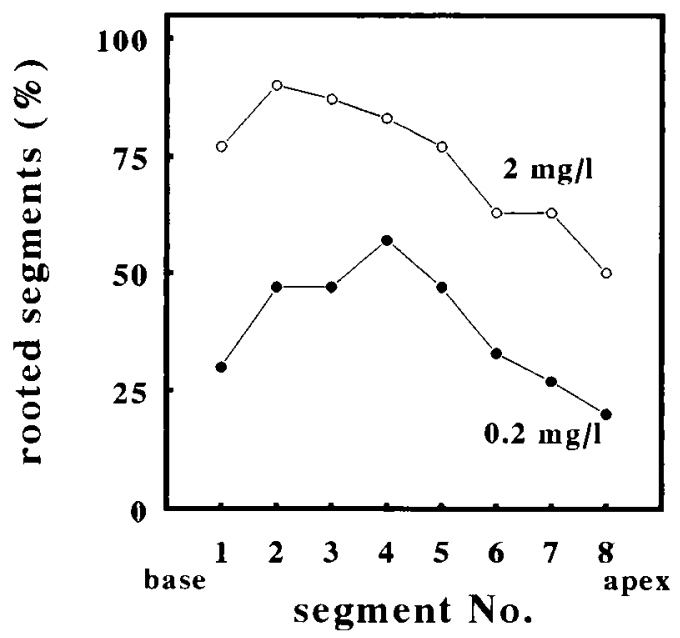

Fig 3. Rooting percentages of shoots of Malus Jork. Shoots of $\mathrm{ca} 2 \mathrm{~cm}$ were divided in 8 equal segments. Rooting was in Petri dishes with addition of 0.2 or 2 mg.l-1 IBA. 


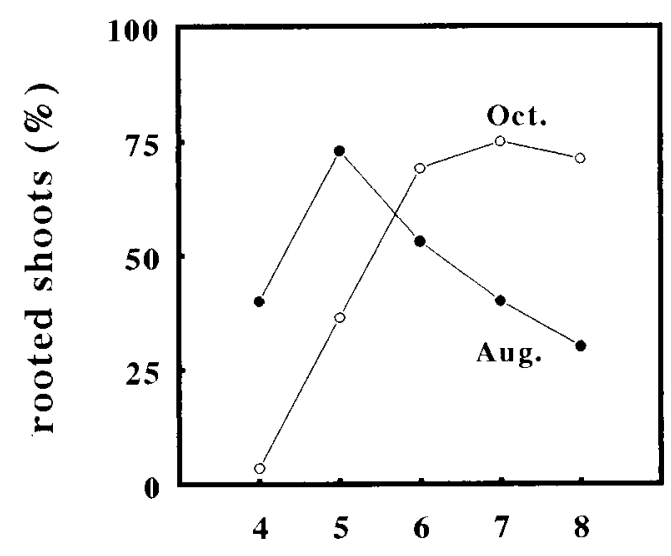

time of harvest (weeks)

Fig 4. Rooting of Malus Elstar. Shoots were harvested from 4-8 wk after subculture. The experiment was performed in 2 successive subculture cycles.

between successive subculture cycles have been frequently observed, but their origin is unclear (Denissen et al, 1992).

We also examined the differences in rooting ability of side- and main-shoots. (The main-shoot is the shoot that originates directly from the transplanted apex). In an experiment in which not only side- and main-shoots were examined, but also side-shoots that had originated from the apices of side-shoots in 3 successive subculture cycles and main-shoots that had originated from apices of main-shoots in the same 3 subculture cycles, the rooting ability was found to be the same (fig 5).

\section{Physiological state}

In Malus cultures vitrification frequently occurs. Vitrified Jork shoots had a rooting percentage of 8 , as opposed to 92 in a sample of normal shoots obtained from the same subculture cycle. It should be noted that during the rooting treatment almost all vitrified shoots had completely recovered. It is known that high cytokinin levels result in vitrification (Paques, 1991). Auxins, which may be considered as cytokinin antagonists, probably counteracted the vitrification.

It has often been suggested that hormones added during the propagation phase have a carryover effect during the rooting phase either because they are still present in the free form, or because they are released from conjugates ( $c f$ Smulders et al, 1990). In Malus shoots, IBA is rapidly taken up by shoots and conjugated for $c a$ 95\% (Van der Krieken et al, 1992). Thus, a high dose of IBA added during the propagation phase might enhance the rooting ability of microcuttings. In the present study, the opposite phenomenon was, however, observed. Low concentrations during propagation had no effect but high concentrations that also reduced proliferation (fig $6 \mathrm{a}$ ) resulted in low rooting percentages (fig 6b). Apparently,
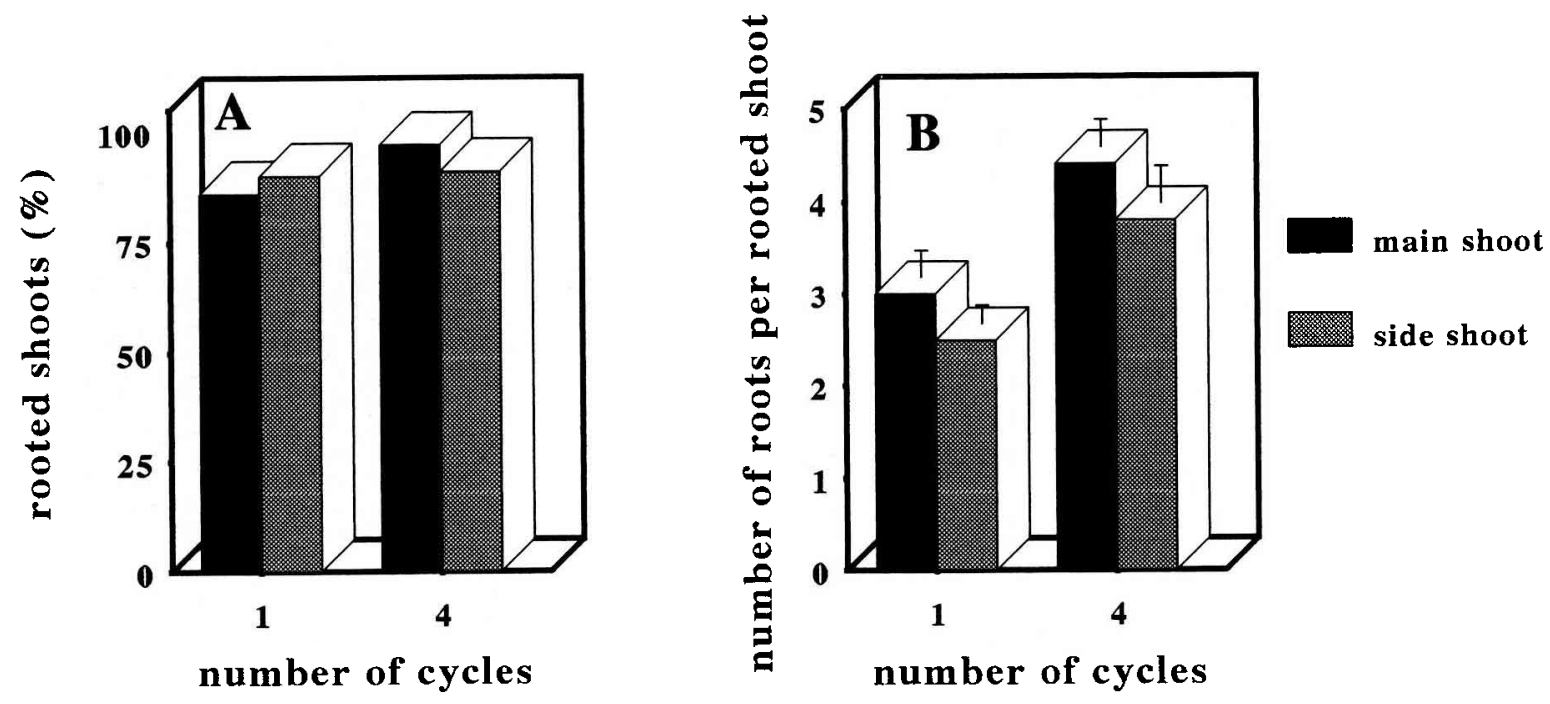

Fig 5. Rooting of main- and side-shoots of Malus Golden Delicious. Main- and side-shoots were either rooted under standard conditions (No of cycles $=1$ ) or transferred to propagation medium and allowed to proliferate for 6 wk. From the latter cultures, main- and side-shoots were harvested, transferred to propagation medium and allowed to proliferate for 6 wk. This was repeated in the following cycle. Then at the end of the 4th cycle, the main-shoots from the 'main-shoot line' and side-shoots from the 'side-shoot line' were rooted. A: percentage of rooting; $\mathbf{B}$ : No of roots per rooted shoot. 

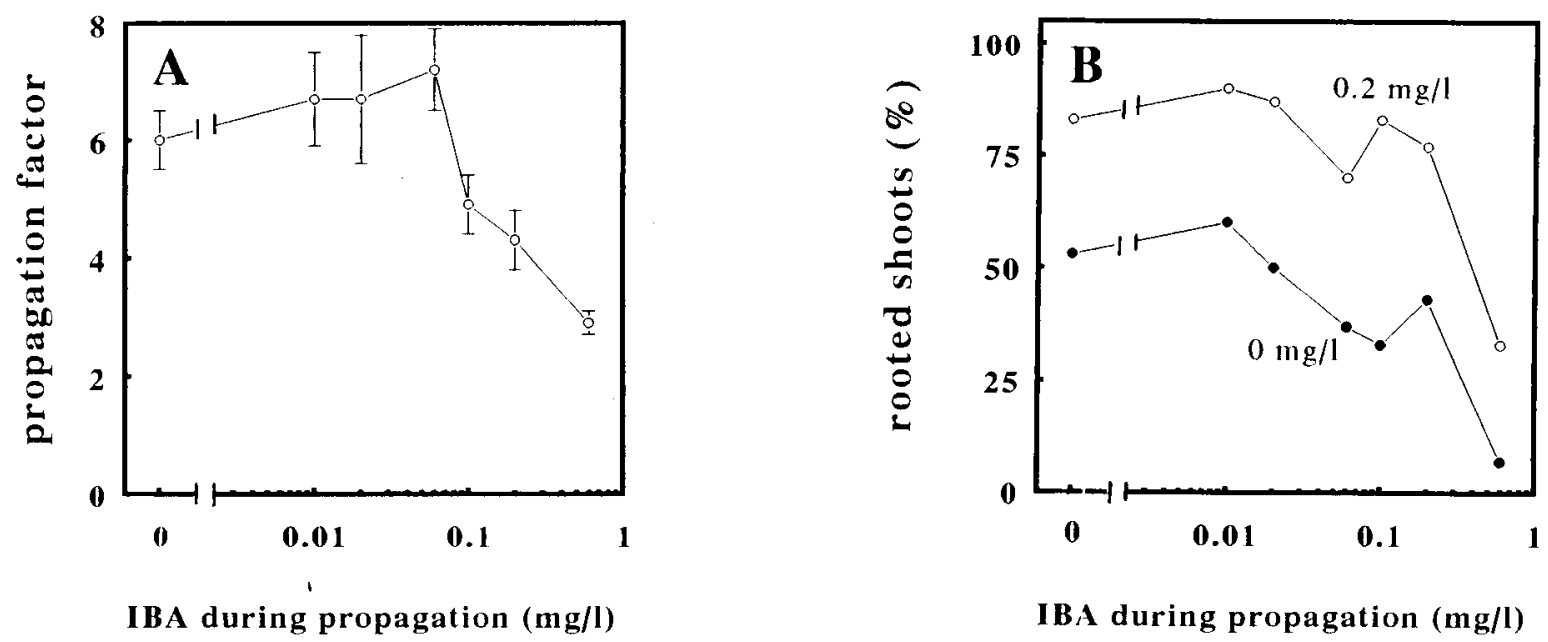

IBA during propagation ( $\mathrm{mg} / \mathrm{l})$

Fig 6. The effect of increasing concentrations of IBA during multiplication on the propagation factor (A) and rooting ability (B) in Malus Golden Delicious. Apical buds were excised and allowed to proliferate in propagation medium with a range of IBA concentrations. After $6 \mathrm{wk}$, the propagation factor $(A)$ and the rooting ability $(B)$ were determined. Rooting was on standard rooting medium (with $0.2 \mathrm{mg} . \mathrm{I}^{-1} \mathrm{IBA}$ ) and on rooting medium in which IBA had been omitted.

the high concentration of IBA during the propagation phase rendered the microcuttings less sensitive to auxin or reduced the ability to form a root.

\section{Conditions during the rooting treatment}

\section{Physical conditions}

For the physical conditions during the rooting treatment, osmotic value of the medium (Rajagopal and Andersen, 1980), temperature (Lê, 1985) and light (James, 1983; Zimmerman, 1984) have been examined previously. We found differences in rooting between temperatures, but could not decide whether this was due to a direct effect of temperature on the regeneration process or to increased uptake of auxin at the high temperature (data not shown).

It has been reported that light reduces ARF (James, 1983; Zimmerman, 1984; Van der Krieken et al, 1992). In an IBA dose-response curve, we observed that there was a slight inhibitory effect of light at low IBA concentrations and a slight promotive effect at high concentrations (fig 7). This may be explained by the photodegradation of IBA in the light (Van der Krieken et al, 1992).

\section{Timing of auxin treatment}

Various authors have observed that auxin should be applied immediately after cutting of the shoot
(Jarvis and Jaheed, 1986) or explant (Attfield and Evans, 1991). Malus shoots cultured for a few days on basal rooting medium (= rooting medium without hormones) prior to the IBA treatment showed a decrease of rooting (fig 8 ). This may have been caused by a reduction in auxin uptake (Jarvis and Jaheed, 1986) after healing of the wound. Preliminary results show that rewounding did not restore the rooting response. We are currently examining in detail the reasons for the loss of rooting ability.

\section{Hormonal factors}

Most researchers have studied the effect of hormones by adding them during the full length of the rooting treatment. The promotive effect of auxins and co-factors (Davis and Haissig, 1990) and the reduction of rooting by cytokinins (Van Staden and Harty, 1988) are well known. Gibberellins, abscisic acid, polyamines, ethylene, brassinosteroids and jasmonic acid have inconsistent effects or have only infrequently been examined (Davis and Haissig, 1990). Auxin is promotive only early on during the rooting treatment and thereafter inhibits outgrowth of the roots (eg De Klerk et al, 1990). This demonstrates that hormones may have different effects in the successive phases of ARF. However, only few studies have been undertaken on this principle. For such a study, the successive phases of rooting have first to be mapped. 


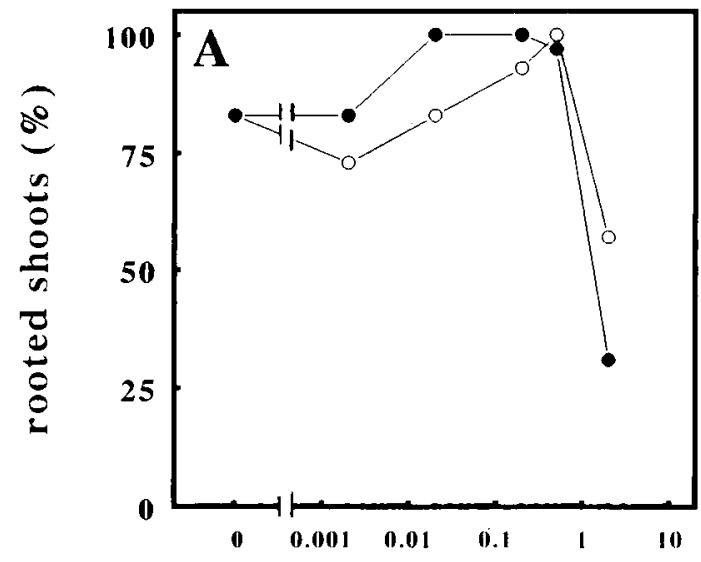

IBA (mg/I)

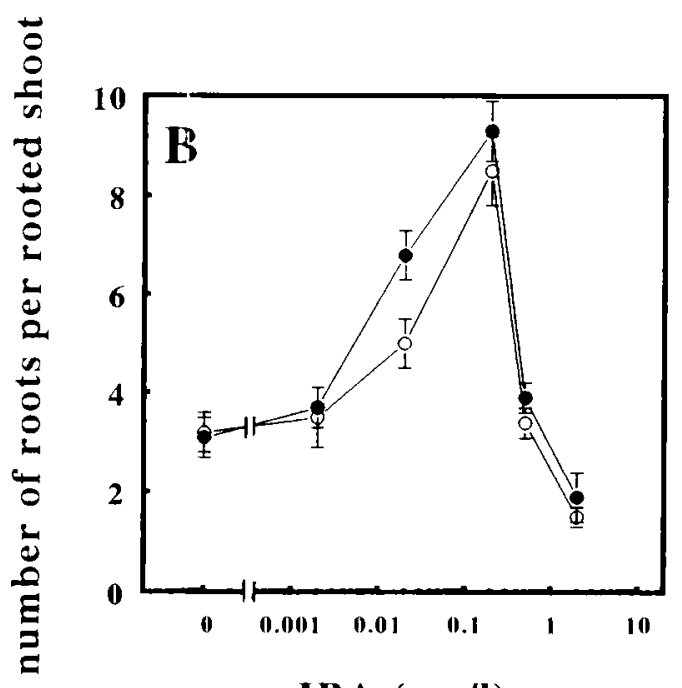

IBA (mg/l)

Fig 7. Rooting of Malus 'Jork' in the light or in the dark at a range of IBA concentrations. A : percentage of rooting; $\mathbf{B}$ : No of roots per rooted shoot. $\rightarrow-$ dark; $-\mathrm{O}-$ light.

\section{Analysis of ARF phases}

The successive steps of ARF have been frequently studied at the microscopic level. However, it cannot be decided via simple microscopic observation whether a group of meristematic cells is a root (pre-)meristemoid or not. The process of root regeneration has also been examined at the biochemical level. Most notably, a characteristic course of basic peroxidase activity has been observed, viz a sharp increase up to the formation of meristematic domes, followed by a decrease during the for-

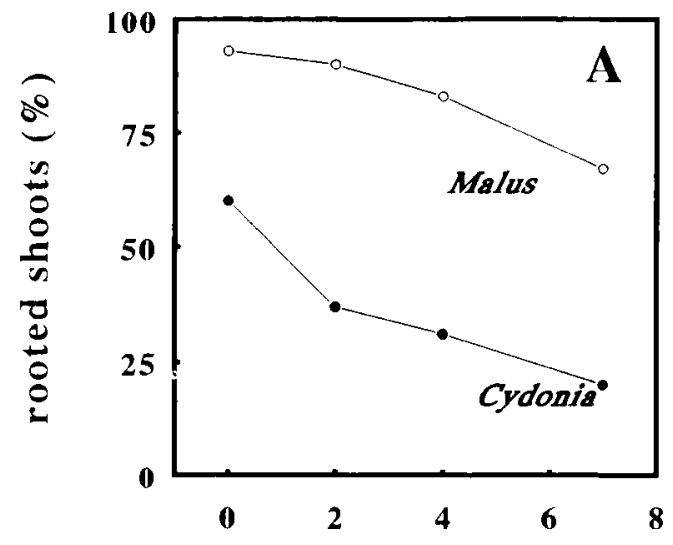

days on basal medium mation of clearly-recognizable root primordia (eg Moncousin and Ducreux, 1984; Berthon et al, 1987; see review in Gaspar et al, 1992). Other authors have not found this course of peroxidase activity (De Klerk et al, 1990). A third means of analysing the various phases of rooting is via the isolation and cloning of mRNAs characteristic for the successive phases. The localization of the specific gene expression within the tissue can be determined by in situ hybridization. Such study is being undertaken by several members of the COST 87 Working Group on Root Regeneration.

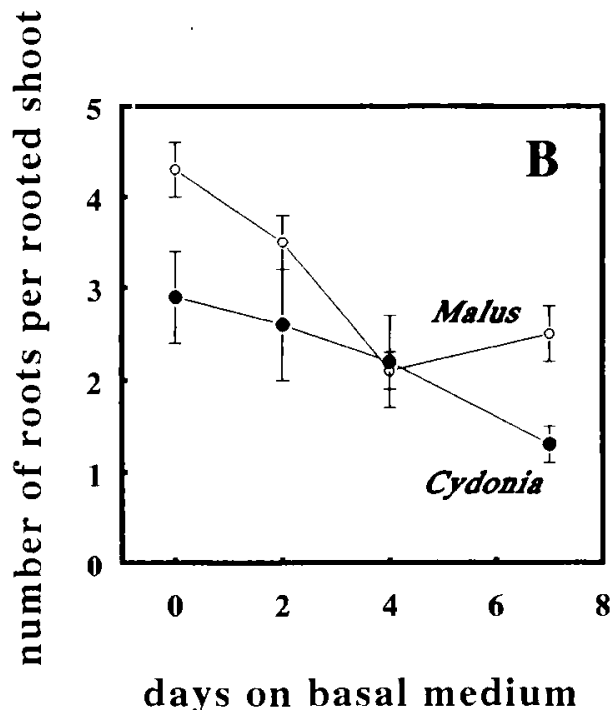

Fig 8. Rooting of Malus 'Jork' and Cydonia oblonga shoots after postponement of the IBA-treatment. Treatment with IBA was for $4 \mathrm{~d}$ and was given after $0,2,4$, or $7 \mathrm{~d}$ preculture of shoots on rooting medium in which IBA had been omitted. A : percentage of rooting; B : No of roots per rooted shoot. 
We have examined the phases in another manner, viz by their different sensitivity towards added hormones. Christianson and Warnick (1983) observed that during the initial period of shoot induction on leaf explants of Convulvus, the explants may be exposed to shoot-, root-, or callus-inducing medium. They concluded that this period represents a period of dedifferentiation during which the tissue becomes competent for the organogenic stimulus. The appropriate auxincytokinin ratio is only required in the next period during which differentiation occurs. In correspondence with this, we assumed that BAP added as a pulse would inhibit rooting most strongly when added during the differentiation phase.

In the period up to $24 \mathrm{~h}$, inhibition by BAP was slight (fig 9). We presume that the first $24 \mathrm{~h}$ during the rooting treatment of Jork shoots also represented a period of dedifferentiation. The 24-h pulse with BAP during the rooting treatment strongly blocked ARF when given between 24-
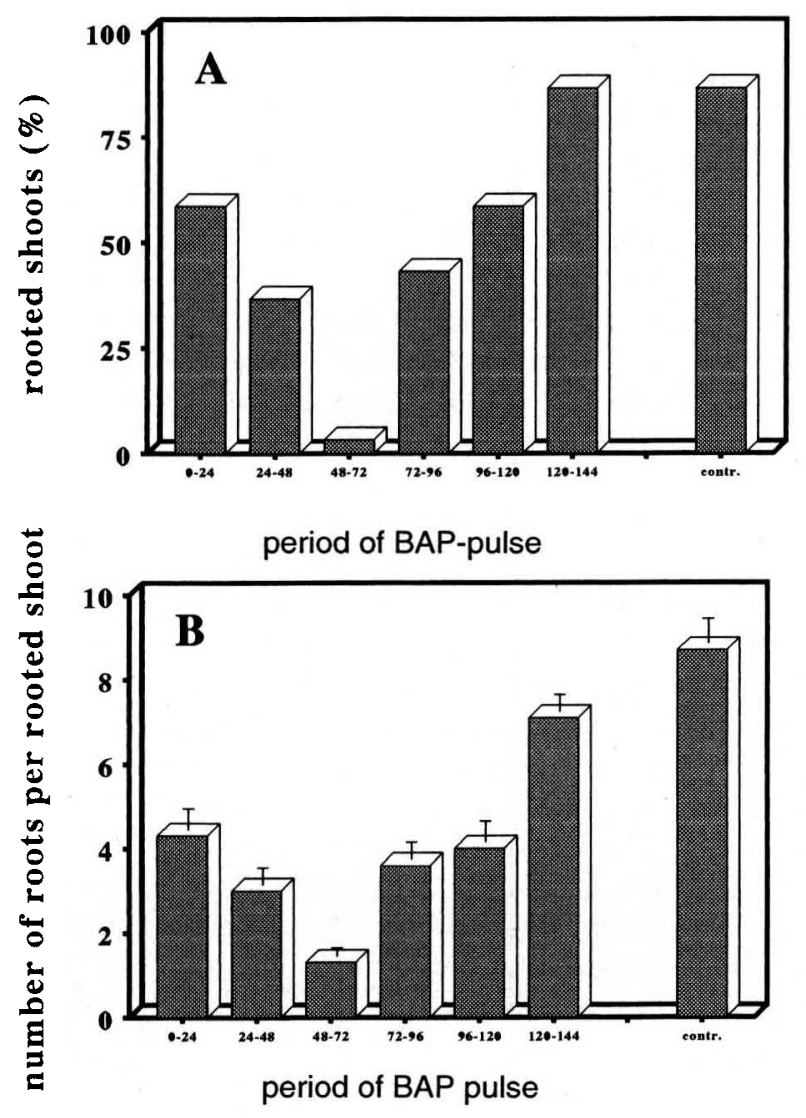

Fig 9. Rooting of Malus Jork shoots after 24-h pulses with BAP at the indicated times. The shoots received the standard

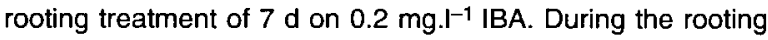
treatment, they were given $0.2 \mathrm{mg} . \mathrm{l}^{-1} \mathrm{BAP}$ at the indicated times. During the BAP pulse, the standard IBA concentration $\left(0.2 \mathrm{mg}^{-1} \mathrm{l}^{-1}\right)$ was also present in the medium. A: percentage of rooting after $13 \mathrm{~d}$; $\mathbf{B}$ : No of rocts per rooted shoot after $21 \mathrm{~d}$.
$96 \mathrm{~h}$ (fig 9), indicating that this was the differentiation period. In correspondence with this, IBA pulses had maximum effect when added during this period (fig 10). In microscopic studies, we found that the first cell divisions occurred after $48 \mathrm{~h}$ (Meekes and de Klerk, unpublished observations). Apparently, the differentiation phase coincided with the first cell divisions. The promotive effect of IBA was not as strong as the inhibitory effect of BAP. This was likely due to the various pitfalls involved in hormone pulses that may be different for BAP and IBA: 1) added hormones may have a carry-over effect: they are present at high levels during the pulse but remain in the tissue, usually to a low percentage in the free non-conjugated form after the pulse; 2) phases other than the differentiation phase may also be promoted or inhibited by auxin or cytokinin respectively, but have different sensitivities; 3) the regeneration of roots in a shoot sample occurs asynchronously (Hicks, 1987). It should also be noted that inappropriate hormonal conditions may have 2 distinct effects: either the process stands still until the adequate hormonal stimulus; or the process is diverted in another direction. Thus, postponement of the addition of IBA may only result in transient arrest of the rooting process, whereas BAP may direct differentiation in another direction.

BAP pulses given after $120 \mathrm{~h}$ hardly inhibited rooting. This indicates that by that time differentiation had been completed, the outgrowth phase had begun. After $9 \mathrm{~d}$, the first roots emerged from the shoots (data not shown). Roots continued to emerge for another $10 \mathrm{~d}$. This indicates

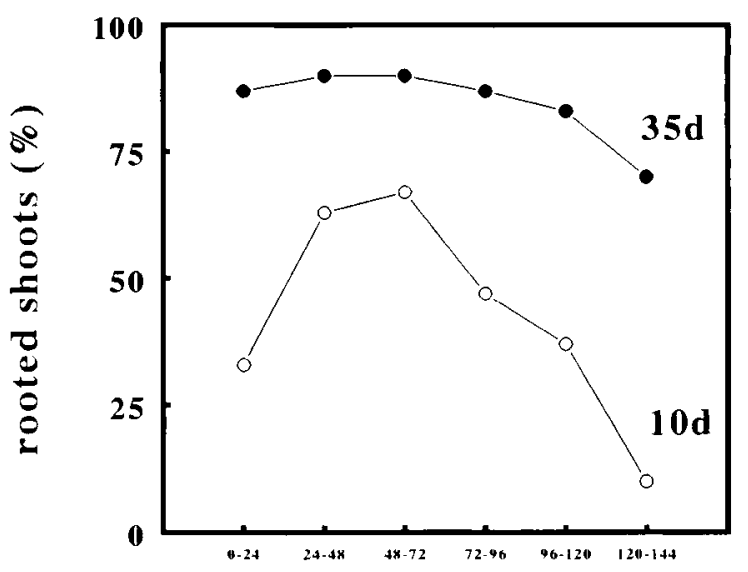

Fig 10. Rooting of Malus 'Jork' shoots after 24-h pulses with IBA at the indicated times. The shoots were cultured on rooting medium in which IBA had been omitted and received a 24-h pulse with $0.5 \mathrm{mg}^{-1} \mathrm{l}^{-1} \mathrm{IBA}$ at the indicated times. The rooting percentage was determined after 10 and $35 \mathrm{~d}$. 
that root regeneration occurred very asynchronously. It is not yet known whether asynchrony is localized in one of the phases (Hicks, 1987).

\section{CONCLUSIONS}

For rooting, the genetic, developmental, positional and physiological condition of the microcutting is essential. We have carried out research in Malus shoots that were easy to root. It remains to be determined whether the factors that have been shown to influence the rooting ability of the shoots have a promotive effect in recalcitrant crops. It should be noted that - as compared to rooting of conventional cuttings - propagation in vitro offers an excellent possibility to study which factors determine the rooting ability of a shoot.

The major leap forward in the study of rooting was made $60 \mathrm{yr}$ ago with the discovery of the effect of auxin. Since then, progress has been slow and no other major factor has been found to achieve rooting of recalcitrant crops. It has been maintained that redirection of research is required (Haissig et al, 1992). For such research it is first necessary to study rooting as a developmental process consisting of various successive phases. The main phases are, as in the regeneration of shoots and somatic embryos - dedifferentiation, differentiation and outgrowth (Christianson and Warnick, 1983). We have established the timing of the differentiation phase. In the future, we will determine how various hormones affect the successive phases. For molecular studies, the timing of the differentiation phase offers the possibilty to isolate specific mRNAs. Such a study will allow identification of the promotors involved and accurate determination of which step in the rooting process is blocked in recalcitrant crops.

\section{ACKNOWLEDGMENTS}

We wish to thank B Kunneman and M Albers for the various cultures and $M$ Keppel for assistance in one of the experiments.

\section{REFERENCES}

Attfield EM, Evans PK (1991) Stages in the initiation of root and shoot organogenesis in cultured leaf ex- plants of Nicotiana tabacum cv, Xanthi nc. J Exp Bot 42, 59-63

Berthon JY, Boyer N, Gaspar T (1987) Sequential rooting media and rooting capacity of Sequoiadendron giganteum in vitro. Peroxidase activity as a marker. Plant Cell Rep 6, 341-344

Christianson ML, Warnick DA (1983) Competence and determination in the process of in vitro shoot organogenesis. Dev Biol 95, 288-293

Cordewener J, Booij $\mathrm{H}$, Van der Zandt $\mathrm{H}$, Van Engelen F, Van Kammen A, De Vries S (1991) Tunicamycininhibited carrot somatic embryogenesis can be restored by secreted cationic peroxidase isoenzymes. Planta 156, 478-486

Davis TD, Haissig BE (1990) Chemical control of adventitious root formation in cuttings. Plant Growth Regul Soc Am Quart 18, 1-18

De Jong AJ, Cordewener J, Lo Schiavo F, Terzi M, Vanderkerckhove J, Van Kammen A, De Vries SC (1992) A carrot somatic embryo mutant is rescued by chitinase. Plant Cell 4, 425-433

De Klerk GJ (1992) Hormonal control of dormancy and apical dominance in tissue-cultured plants. Acta Bot Neerl (in press)

De Klerk GJ, Ter Brugge J, Smulders R, Benschop M (1990) Basic peroxidases and rooting in microcuttings of Malus. Acta Hortic 280, 29-36

Delvallé I, Paffen A, De Klerk GJ (1990) The development of dormancy in bulblets of Lilium speciosum generated in vitro. 2. The effect of temperature. Physiol Plant 80, 431-436

Denissen CJM, De Klerk GJM, Albers MRJ, Ter Brugge J, Kunneman BPAM (1992) Effect of accidental factors on rooting of Malus 'Golden Delicious'. Agronomie 12, 799-802

Gaspar T, Kevers C, Hausman JF, Berthon JY, Ripetti $V$ (1992) Practical uses of peroxidase activity as a predictive marker of rooting performance of micropropagated shoots. Agronomie 12, 757-765

Hackett WP (1985) Juvenility, maturation and rejuvenation in woody plants. Hortic Rev 7, 109-155

Haissig BE, Riemenschneider DE (1988) Genetics effects on adventitious rooting. In: Adventitious Root Formation in Cuttings (Davis TD, Haissig BE, Sankhla N, eds) Dioscorides Press, Portland, OR, 47-60

Haissig BE, Davis TD, Riemenschneider DE (1992) Researching the controls of adventitious rooting. Physiol Plant 84, 310-317

Hansen J (1986) Influence of cutting position and stem length on rooting of leaf-bud cuttings of Schefflera arboricola. Sci Hortic 28, 177-186

Hicks GS (1987) Adventitious rooting of apple microcuttings in vitro: an anatomical study. Can J Bot 65, 1913-1920

James DJ (1983) Adventitious root formation 'in vitro' in apple rootstocks (Malus pumila) I. Factors affecting the length of the auxin-sensitive phase in M.9. Physiol Plant 57, 149-153 
Jarvis BC, Shareed Al (1986) Auxin uptake, transport and accumulation in relation to rooting and ageing of mung bean cuttings. Biochem Physiol Pflanz 181, 597-604

Lê CL (1985) Influence of temperature on in vitro root initiation and development of apple rootstock M26. Hortsci 20, 451-452

Moncousin C, Ducreux G (1984) Activité peroxydasique et rhizogenèse dans le cas de Cynara scolymus $L$ : évolution au cours de repiquages successifs de boutures cultivés in vitro. Comparaison avec de jeunes plantes issues de graines. Agronomie 4, 105-111

Paques M (1991) Vitrification and micropropagation: causes, remedies and prospects. Acta Hortic 289, 283-190

Powell LE (1987) Hormonal aspects of bud and seed dormancy in temperate-zone woody plants. HortSci 22, 845-850

Rajagopal V, Andersen AS (1980) Water stress and root formation in pea cuttings. 1. Influence of the degree and duration of water stress on stock plants grown under two levels of irradiance. Physiol Plant 48, 144-149

Reisch B, Bingham ET (1980) The genetic control of bud formation from callus cultures of diploid alfalfa. Plant Sci Lett 20, 71-77
Smulders MJM, Van de Ven ETWM, Croes AF, Wullems GJ (1990) Metabolism of 1-naphthalene acetic acid in explants of tobacco: evidence for release of free hormone from conjugates. J Plant Growth Regul 9, 27-34

Thimann KV, Went FW (1934) On the chemical nature of the root forming hormone. Proc $K$ Ned Acad Wet Ser C Biol Med Sci 37, 456-459

Van der Krieken WM, Breteler H, Visser MHM, Jordi $W$ (1992) Effect of light and riboflavin on indolebutyric acid-induced root formation on apple in vitro. Physiol Plant 85, 589-594.

Van Staden J, Harty AR (1988) Cytokinins and adventitious root formation. In: Adventitious Root Formation in Cuttings (Davis TD, Haissig BE, Sankhla N, eds) Dioscorides Press, Portland, OR, 185-201

Van Telgen HJ, Van Mil A, Kunneman B (1992) Effect of propagation and rooting conditions on acclimatization of micropropagated plants. Acta Bot Neerl (in press)

Wise FC, Blazich FA, Hinesley LE (1985) Propagation of Abies fraseri by semidormant hardwood stem cuttings. HortSci 20, 1065-1067

Zimmerman RH (1984) Rooting apple cultivars in vitro: interactions among light, temperature, phloroglucinol and auxin. Plant Cell Tissue Organ Cult 3, 301-311 